\title{
Towards Improved Teaching Effectiveness in Nigerian Public Universities: Instrument Design and Validation
}

\author{
Ijeoma Aniedi Archibong \\ Department of Educational Foundations \& Administration, Faculty of Education \\ Cross River University of Technology, Calabar, Nigeria \\ E-mail: anije1997@yahoo.com \\ Mbe Egom Nja \\ Department of Mathematics and Statistics, Faculty of Science \\ Cross River University of Technology, Calabar, Nigeria \\ E-mail: mbe_nja@yahoo.com
}

Received: May 23, 2011

Accepted: June 16, 2011

Published: December 1, 2011

doi:10.5539/hes.v1n2p78

URL: http://dx.doi.org/10.5539/hes.v1n2p78

\begin{abstract}
This research is conducted to examine what is currently evaluated with respect to teaching in Nigerian public universities and to produce instruments that would be useful for examining the course and teaching effectiveness of course lecturers. Telephone interview of ten (10) professors in ten public Nigerian Universities is used to elicit information on the current state of evaluation of teaching while a document analysis reveals the concerns of National Universities Commission with lecturers during programme accreditation. Finding indicates that teaching effectiveness is grossly ignored in the lecturer appraisal process. An 18 item questionnaire and another 15 item questionnaire measuring teaching and course effectiveness respectively is constructed. After a test retest procedure using four lecturers and four courses, the instruments yielded a reliability coefficient ranging from -0.568 to 0.591 for lecturers and 0.548 to 0.944 for the courses. The correlation coefficient values clearly reveal that the course evaluation and lecturers' evaluation forms were adequate to generate information on the course and lecturer effectiveness. It is therefore recommended, among other things that the National Universities Commission (NUC) as a regulatory body should make the evaluation of teaching a mandatory policy for all universities.
\end{abstract}

Keywords: Teaching effectiveness, Evaluation, Lecturers, Validation, Reliability

\section{Introduction}

Nations of the World have come to rely on the three-fold function of the university - teaching, research and community service as a means to advancement in knowledge, production of qualified workforce and social and economic transformation. In order to gain these benefits, many countries are taking steps to ensure quality education delivery aimed at maintaining and improving teaching, learning, research and scholarship in the universities. Of particular interest is the quality of teaching, a critical factor in students' success. The close link between students' achievement and effective teaching has made its assurance a dominant concern in both developed and developing nations. This concern has brought much pressure on tertiary educational institutions. This in turn has led many institutions to lay a greater emphasis on teaching and the need for specific and measurable evaluation of teaching (Frost and Fukami, 1997). The appropriate evaluation of the effectiveness of instruction is a matter of major importance to all educational institutions (Cadden, Dricoll \& Thompson, 2008). Several strategies to measure teaching effectiveness such as student ratings, peer evaluation, self evaluation etc have been used by tertiary educational institutions. However, use of student ratings has generated more interest than any other teaching effectiveness evaluation strategy.

In Nigeria, the controversy that arose on the use of students to rate teaching effectiveness in universities rages on. Maiwada (2001) posited that the inability of stakeholders in education to evaluate the standard of classroom teaching has contributed to the falls in the standard of education in Nigeria. In reaction to the opposition to a trial of a new system of evaluating academic staff that would involve students' assessment of academic staff performance proposed by the rector of the Delta State Polytechnic, Ozoro, Obijiofor (2005) asserted that academic staff members 
who have operated unchecked like lords over the years do not like a system of performance appraisal that would require them to demonstrate on a yearly basis evidence of innovativeness in teaching. The works of Iyamu and Adum-Oglebgen (2005) showed that university lecturers in Nigeria generally have a low perception of the need for student evaluation, while Idaka, Joshua \& Kritsonis (2000) held that the sampled Nigerian academic staff showed a significantly positive attitude to Student Evaluation of Instruction (SEI). Both studies, however, found that academic staff are more accepting to SEI when the purpose to be served is formative rather than summative. The foregoing so far has established lecturers' disposition to student evaluation of their teaching. However, there is a need in practice to establish what is currently evaluated with respect to teaching in Nigerian public Universities and to develop an instrument for rating course and quality of instruction.

\section{Literature Review}

The use of student for evaluation of instructional effectiveness has continued to receive attention from school administrators and researchers. Although there are other means of collecting information on evaluating instruction, historically, student ratings have dominated as the primary measure of teaching effectiveness for the past 30 years (Seldin, 1999). Still in line with this view Cladden, Driscoll \& Thompson (2008) posited that one method used extensively to aid in determining instruction effectiveness is Student Evaluation of Instruction (SEI). Also, Emery, Kramer, \& Tian (2003) opined that student ratings is the most influential measure of performance used in promotion and tenure decisions at institutions that emphasize teaching effectiveness.

Research indicates that students are the most qualified sources to report on the extent to which the learning experience was productive, informative, satisfying or worthwhile. While opinions on these matters are not a direct measure of instructor or course effectiveness, they are legitimate indicators of student satisfaction, and there is a substantial research linking student satisfaction to effective teaching (Theall and Franklin, 2001). According to Richmond (2003) and Clifford (1999) student opinion is of particular importance because it represents an important addition to the data customarily used to judge faculty competence. It is the one source of direct and extensive observation of the way teachers carry out their daily and long-range tasks.

Research emphasis on student rating of teaching effectiveness stems from the benefit that such evaluations contribute to quality in the educational process. Student evaluations of teaching effectiveness are used primarily to give feedback to faculty for instructional improvement and to make personnel and administrative decisions (Centra, 1993; Marsh \& Roche 1993). Research evidence equally suggests an agreement among the experts on faculty evaluation that student ratings provide an excellent source of evidence for both formative and summative decision (Arreola, 2000; Centra, 1999; Seldin, 1999). The benefits that students' ratings can have on an institution include the following:

- Instructors value the input and make improvements in their teaching.

- Instructors are rewarded for having excellent rating

- Instructors with very low ratings are encouraged to seek help

- Students perceive and use ratings as a way to suggest improvements in teaching

- Students have more information on which to make their course selections.

- Ratings motivate instructors to improve teaching

- $\quad$ Students see ratings as a vehicle for change. (Ory and Ryan, 2001).

The accuracy of students' rating instrument in measuring a lecturer's teaching effectiveness has continued to generate a lot of argument. In essence the validity and reliability of such an instrument is called to question. Works by Morgan, Sneed and Swinney (2003), Clayson and Sheffet (2006), and Glynn, Saver and Wood (2006) lend support to the view that Student Evaluation of Instruction (SEI) are valid instruments. Murray (1994) held that research on student evaluation of teaching generally concludes that student ratings tend to be reliable, relatively unbiased and useful. Nassar and Fresko (2002) asserted that at present, a large percentage of faculty in all disciplines exhibit moderately positive attitudes toward the validity of student ratings and their usefulness in improving instruction; however, there is no consensus. They further posited that in spite of the popularity of student ratings of faculty performance, there have also been signs of faculty hostility and cynicism towards student ratings. Student ratings are a necessary source of evidence of teaching effectiveness for both formative and summative decisions, but not a sufficient source for the latter. Considering all of the polemics over its value, it is still an essential component of any faculty evaluation system (Berk, 2005). 
Another issue is the competence of students to accurately evaluate the teaching effectiveness of the faculty. Authors like Bures and Newton (1980), DeRidder and Tong (1990) are of the opinion that students cannot evaluate.

\section{The Study Problem}

The change occurring in the provision of higher education demands in part, innovativeness in teaching and assurance in its quality. In most universities in the western world, measurable standards for teaching performance evaluation have been established. These include student ratings of instruction. However, this is not the case with Nigerian public universities. Given this prevailing situation this study aims at:

i. Establishing what is currently assessed with regard to teaching in the appraisal process of academic staff

ii. Developing and validating instruments for use in teaching effectiveness and course evaluation.

To achieve the first objective of this paper two research questions are posed.

i. Is teaching assessed during academic staff appraisal in Nigerian public universities?

ii. Is teaching given due attention during programme accreditation by the National Universities Commission (NUC).

\section{Method}

In line with the aims of the study, survey research design was adopted to ascertain what was currently assessed with respect to teaching. This involved asking a structured question through telephone interview of professors in 10 Nigerian public universities namely- University of Lagos (UNILAG), University of Ilorin (UNIILORIN), University of Calabar (UNICAL), Abubakar Tafawa Belewa University (ATBU), University of Uyo (UNIUYO), University of Ibadan (UI), Cross River University of Technology (CRUTECH), Imo State University (IMSU), Abia State Univeristy (ABSU) and Lagos State University (LASU). These professors are involved in academic staff appraisal in their universities. In order to determine what the National Universities Commission (NUC) evaluate as pertaining to teaching staff during program accreditation a document analysis was done utilizing the NUC's manual of accreditation procedures for academic programmes in Nigerian universities.

To achieve the third aim of the study which involve the development and validation of lecturer and course evaluation forms, the researchers developed an 18 item and 15 item questionnaires for students to evaluate the lecturer's teaching effectiveness and the course respectively. All the items in the two instruments were measured in a 5 point Likert-like scale of Strongly Agree (SA); Agree (A); Not Sure (NS); Disagree (D); and Strongly Disagree (SA). The items were first face validated by a professor in measurement and evaluation and another lecturer with a $\mathrm{Ph} . \mathrm{D}$ in teacher education. The two assessors modified some items in the process of validating the instruments. The test-retest method was adopted to establish the reliability of the instrument. This involved using different academic staff in the Department of Math/Statistics in the faculty of Science and Department of Educational Foundations and Administration in the Faculty of Education in Cross River University of Technology, Calabar.

Three lecturers and the three courses they teach in the faculty of science were evaluated by the same group of students while one lecturer and the course taught were evaluated by a single group of students in the Faculty of Education. This brings to a total of four lecturers and four courses in the two faculties. This blocking is introduced in order to systematically control variability that may be attributed to extraneous factors. In order to ensure adequacy of sample size, Franklin and Theall (1991) recommended ideal class size proportion as outlined below is adapted.

$$
\begin{array}{cc}
\text { Class Size } & \text { Recommended Responses } \\
5-20 & 80 \% \\
20-30 & 75 \%
\end{array}
$$

In the Department of Mathematics/Statistics 14 out of a total number of 17 students representing $82.3 \%$ responded to the instruments. In the Department of Educational Foundations and Administration 23 out of 30 students representing $76.6 \%$ responded to the instruments. In each case the evaluation was replicated in a test-retest design. One group of students was used on three lecturers on both test and retest exercises in order to control variability that may be caused by discrepancies due to unexplained factors, like group opinion/experience, departmental experience, and so on. The lecturers and the courses were evaluated in terms of each student's opinion using an 18-item questionnaire for the lecturers and a 15-item questionnaire for the courses. Students' scores with respect to lecturers, courses and items in both questionnaires were correlated yielding 16 correlation coefficients for the four lecturers and four courses.

The Pearson Product Moment Coefficient of Correlation was used in the analysis with the aid of the SPSS software. 


\section{Findings and Discussion}

5.1 RQ 1: What is currently assessed with respect to teaching in your university and what weight is assigned to it in the academic staff appraisal process?

Excerpts from telephone interviews of professors in public universities with regard to this research question are presented below.

UNILAG: Teaching is not scored during appraisal, the Head of Department comments on the lecturer's teaching in the appraisal form, but this does not attract scores. But there is a proposal currently being considered to include student ratings in lecturer evaluation.

UNIILORIN: Teaching attracts a maximum of 10 points during appraisal. It is awarded based on years of teaching experience in tertiary educational institution. A year attracts 1 point until the lecturer attains the maximum 10 points.

UNICAL: Teaching is not allotted any score during appraisal. The lecturer simply lists the courses taught in the last three years. The head of department comments on it in terms of adequacy of teaching workload to the lecturer's rank, but this does not attract any score.

ATBU: The courses taught by the lecturer's and other administrative responsibilities are indicated in the appraisal form for viewing by the appointment and promotion committee, but no scores are awarded for these.

UNIUYO: Teaching is currently not scored during the appraisal process. The courses a lecturer teaches are simply listed on the appraisal form for viewing but there is no score attached to it. Modalities for assessing teaching are currently being looked into in the university.

UI: Teaching load of the lecturer is usually viewed in the appraisal form. However, no weight is allotted to teaching; the scores are based on the publication. The institution is currently working on modalities for including scores for teaching during academic staff appraisal.

CRUTECH: It is generally assumed that a lecturer who satisfies the maturity criterion for promotion has taught effectively. This justifies the lecturer's recommendation at the departmental and faculty appraisal levels. But no specific score is allotted to teaching.

IMSU: Teaching is only considered for promotion of junior academic staff cadre that is Assistant Lecturer to Lecturer I. it is generally assumed that for anybody due promotion from the rank of senior lecturer upwards, the person has met the teaching requirements for a lecturer. Hence, the emphasis is on their publications.

ABSU: Teaching only attracts a score during promotion junior academic staff. At senior cadre level, the concern is with the publications.

LASU: Teaching attracts a maximum of 10 marks during appraisal of staff for promotion. It is awarded based on years of teaching experience and assessment by the head of department.

A critical appraisal of the responses to the research question shows that none of the universities indicated currently assesses the quality of teaching. Rather in some universities where scores are awarded, it is for teaching experience and adequacy of teaching load. This implies that the published or perish syndrome is ruling in the evaluation of academic staff since the scores are mainly derived from publications. In essence, a lecturer that has deficiencies in teaching can still rise up to the rank of professor provided the individual meets the publication requirements. The ramification of this state of affairs can only be imagined in considering quality of graduates.

\subsection{RQ2: What does National Universities Commission (NUC) Evaluate with respect to teaching staff during programme accreditation?}

The NUC (1999) maintains that the adequacy of the teaching staff determines the adequacy of the programme as the instructional goal and objectives are achieved only to the level of competence and vision of the teaching staff. In accrediting a programme the NUC considers adequacy of the teaching staff in numbers, competence and standard of instruction in all subject areas of the programme. This consideration is achieved by evaluating the following components under teaching staff sub-heading.

i. The Staff/Student Ratio: The staff/student ratio attracts 10 as maximum score. It is awarded based on the extent to which the actual staff/student ratio complies with the provisions of the Minimum Academic Standard (MAS).

ii. The Staff Mix by Rank: The staff structure for academic staff is expected to 20: 35: 45 for professors/ readers: Senior Lecturers: Lecturer I and below respectively. This attracts 6 as maximum score depending on the extent of compliance to this stipulated staff mix ratios. 
iii. Qualification: This attracts a maximum of 3 points and is awarded based on the percentage of academic staff that has a Ph.D.

iv. Competence: The overall competence of the teaching staff may be judged by such factors as:

- The level of academic and / or professional training

- Their cognate teaching experience and professional work

- The diversity of their background

- The extent to which they further their own education in relevant program that are offered in the College/School/Faculty/Department.

- The degree of their participation in profession associations/ societies.

- The existence of a staff development programme for the improvement of the teaching fore and curriculum (NUC, 1999).

v. Staff Development: The NUC (1999) maintains that any improvement in the teacher through schemes of staff development improves the curriculum and the quality of teaching that the students receive. Staff development attracts a maximum of 2 points and is awarded based on the number of academic staff that have benefitted from staff development programme in the past five years. This may be in the form of staff that have upgraded and updated their competencies through seminars, industrial attachment, degree and higher degree courses.

There is no doubt that these indices of measuring academic staff quantity and quality by NUC are very important. Institutions that attain these requirements are sure to have their programmes accredited. However, worthy of note is the fact that none of these indices captures what actually transpires in the classroom between the lecturer and the students in terms of teaching.

\subsection{Results of Instrument Validation}

The results of the test retest analysis for the lecturer effectiveness and course form evaluation are presented in Tables 1-16, while the summary is presented in Table 17.

All the 16 coefficients were significant. Eight of the 16 coefficients were significant at 0.05 and the other eight were at 0.01 significance level. The SPSS outputs table 1-16 confirms the significance of all the 16 correlation coefficients thus proving the reliability of the instruments. Establishing the reliability of the items measuring the lecturer's effectiveness was carried out because the items are intended to reveal the strength and weaknesses of the staff.

\section{Conclusion}

Quality assurance in tertiary educational institutions is a global concern. This study reveals that teaching effectiveness is currently not assessed and does not form part of the conditions for promotion of academic staff in many Nigerian public universities. This implies that the gains that accrue as a result of evaluation of teaching, particularly in terms of improvement in the quality of the teaching- learning process are lost. Lecturers in these universities will not have feedback on the quality of their teaching and may continue to make errors that would have been corrected through the evaluation process. The students also will not have the opportunity to make input that may enhance the learning process. These validated instruments if adopted by university management as part of their quality assurance measures will significantly address the problem of non- evaluation of teaching and thus improve staff development efforts in these universities.

\section{Recommendation}

Based on the findings of this study it is recommended as follows:

i. That these instruments validated in this study be adopted as part of appraisal documents for formative and staff development purposes.

ii. That universities that have not yet instituted teaching evaluation as part of their quality assurance measure should do so.

iii. The National Universities Commission (NUC) as a regulatory body should make evaluation of teaching a mandatory policy for all universities.

\section{References}

Arreola, R. A. (2000). Developing a comprehensive faculty evaluation system: A handbook for college faculty and administrators on designing and operating a comprehensive faculty evaluation system. ( ${ }^{\text {nd }}$ Ed.) Bolton, M. A.: Anker. 
Berk, R. A. (2005). Survey of 12 strategies to measure teaching effectiveness. International journal of teaching and learning in higher education, 17(1), 48-62

Bures, A. L., DeRidder, J. J., \& Tong, H. M. (1990). An empirical study of accounting faculty evaluating system. The Accounting Educators' Journal (Summer), 68-76

Cadeen, D., Driscoll, V., \& Thompson, M. (2008). Improving teaching effectiveness through the application of SPC methodology. College teaching methods \& styles journals, 4(11), 33-46

Centra, J. A. (1993). Reflective faculty evaluation. San Francisco: Jossey-Bass.

Centra, J. A. (1999). Reflective faculty evaluation: Enhancing teaching and determining faculty effectiveness. San Francisco: Jossey-Bass.

Clayson, D. E., \& Sheffet, M. J. (2006). Personality and the student evaluation of teaching. Journal of marketing education, 28(2), 149-160. http://dx.doi.org/10.1177/0273475306288402

Clifford, R. (1999). Quality control in College teaching. Issues in college teaching, 9(2), 11-20

Emery, C. R., Kramer, T. R., \& Tian, R. G. (2003). Return to academic standards: A critique of students' evaluation of teaching effectiveness. Quality assurance in education: An international perspective, 11(1), 37-47

Frost, P., \& Fukami, C. (1997). Teaching effectiveness in the organizational sciences: Recognizing and enhancing the scholarship of teaching. Academic of Management Journal, 40(6), 1271-1281. http://dx.doi.org/10.2307/257033

Glynn, J. G., Saver, P. L., \& Wood, G. R. (2006). Dimensionality of a student evaluation of teaching scale: A ten year review. Academy of Educational Leadership Journal, 10(2), 45-53

Idaka, I. I., Joshua, M. T., \& Kritsonis, W. A. (2006). Attitude of Academic Staff in Nigerian Tertiary Educational Institutions to Student Evaluation of Instruction (SEI). International Journal of Scholarly Academic Intellectual Diversity $9(1)$.

Iyamu, E. O. S., \& Aduwa-Ogledaen, S. E. (2005). Lecturers' perception of student evaluation in Nigerian universities. Intervention Education Journal, 6(5), 619-625

Maiwada, D. A. (2001). Non-evaluation of lecturers, bane of education. In Nigeria University System News, 10(3), $12-15$

Marsh, H. W., \& Roche, L. A. (1993). The use of students' evaluations and an individually structured intervention to enhance university teaching effectiveness. American educational research journal, 30(1), 217-251. http://dx.doi.org/10.2307/1163195

Morgan, D. A., Sneed, J., \& Swinney, L. (2003). Are student evaluation a valid measure of teaching effectiveness: perceptions of accounting faculty members and administrators. Management Research News, 26(7), 17-32. http://dx.doi.org/10.1108/01409170310783565

Murray, H. G. (1994). Can teaching be improved? Brock University: Ontario, Canada.

Nassar, F., \& Fresko, B. (2002). Faculty views of student evaluation of college teaching. Assessment \& Evaluation in Higher Education. 27(2), 187-198. http://dx.doi.org/10.1080/02602930220128751

Newton, J. D. (1988). Using Student Evaluation of Teaching in Administrative Control: The Validity Problem. Journal of Accounting Education, 6(1), 1-14. http://dx.doi.org/10.1016/0748-5751(88)90033-4

NUC. (1999). Manual of accreditation procedures for academic programmes in Nigerian Universities. Abuja: NUC.

Obijiofor, L. (2005). Pathways to quality higher education. [Online] Available: http://www.nigeriavillagesquare.com/articles/levi-obijiofor/pathways-to-quality-in-higher-education html (July 27, 2010)

Ory, J. C., \& Ryan, K. (2001). How do student ratings measure up to new validity framework? In M. Theall P. Abrami and L. Mets (Eds.), The student ratings debate: Are they valid? How can we best use them? New directions for instructional research, No. 109, San Francisco: Jossey-Bass.

Richmond, E. (2003). Looking at good teaching. Educational evaluation, 35(1), 48-59

Seldin, P. (1999). Current practices - good and bad-nationally. In P. Seldin \& Associates (Eds.). Changing practices in Evaluating Teaching: A practical guide to improve faculty performance and promotion/tenure decisions. Bolton, MA: Anker. pp. 1-24. 
Theall, M., \& Franklin, J. (2001). (Eds.) "Looking for bais in all the wrong places - A search for truth or a witch hunt in student rating of instructions?" in the student ratings debate: Are they valid? How can we best use them? P. Theall, L. Abrami and L. Mets (Eds.). New direction is educational research. No. 109. Sen Francisco: Jossey-Bass.

Table 1. Correlations

\begin{tabular}{|cl|c|c|}
\hline & & LECTA1 & LECTA2 \\
\hline LECTA1 & Pearson Correlation & 1 & $-.567\left(^{*}\right)$ \\
& Sig. (2-tailed) & & .034 \\
& $\mathrm{~N}$ & 14 & 14 \\
LECTA2 & Pearson Correlation & $-.567(*)$ & 1 \\
& Sig. (2-tailed) & .034 & 14 \\
\hline
\end{tabular}

* Correlation is significant at the 0.05 level (2-tailed).

Table 2. Correlations

\begin{tabular}{|ll|c|c|}
\hline & & ILECTA1 & ILECTA2 \\
\hline ILECTA & Pearson Correlation & 1 & $.522\left(^{*}\right)$ \\
& Sig. (2-tailed) & & .026 \\
& $\mathrm{~N}$ & 18 & 18 \\
ILECTA & Pearson Correlation & $.522\left(^{*}\right)$ & 1 \\
& Sig. (2-tailed) & .026 & 18 \\
\hline
\end{tabular}

* Correlation is significant at the 0.05 level (2-tailed).

Table 3. Correlations

\begin{tabular}{|ll|c|c|}
\hline & & LECTB1 & LECTB2 \\
\hline LECTB1 & Pearson Correlation & 1 & $.546\left(^{*}\right)$ \\
& Sig. (2-tailed) & & .043 \\
& $\mathrm{~N}$ & 14 & 14 \\
LECTB2 & Pearson Correlation & $.546\left(^{*}\right)$ & 1 \\
& Sig. (2-tailed) & .043 & 14 \\
\hline & $\mathrm{N}$ & 14 & \\
\hline
\end{tabular}

* Correlation is significant at the 0.05 level (2-tailed). 
Table 4. Correlations

\begin{tabular}{|cl|c|c|}
\hline & & ILECTB1 & ILECTB2 \\
\hline ILECTB1 & Pearson Correlation & 1 & $.475\left(^{*}\right)$ \\
& Sig. (2-tailed) & & .046 \\
& $\mathrm{~N}$ & 18 & 18 \\
ILECTB2 & Pearson Correlation & $.475\left(^{*}\right)$ & 1 \\
& Sig. (2-tailed) & .046 & \\
& $\mathrm{~N}$ & 18 & 18 \\
\hline
\end{tabular}

* Correlation is significant at the 0.05 level (2-tailed)

Table 5. Correlations

\begin{tabular}{|cl|c|c|}
\hline & & LECTC1 & LECTC2 \\
\hline LECTC1 & Pearson Correlation & 1 & $.591\left(^{*}\right)$ \\
& Sig. (2-tailed) & & .026 \\
& $\mathrm{~N}$ & 14 & 14 \\
LECTC2 & Pearson Correlation & $.591\left(^{*}\right)$ & 1 \\
& Sig. (2-tailed) & .026 & \\
& $\mathrm{~N}$ & 14 & 14 \\
\hline
\end{tabular}

* Correlation is significant at the 0.05 level (2-tailed)

Table 6. Correlations

\begin{tabular}{|cl|c|c|}
\hline & & ILECTC1 & ILECTC2 \\
\hline ILECTC1 & Pearson Correlation & 1 & $.901\left(^{* *}\right)$ \\
& Sig. (2-tailed) & & .000 \\
& $\mathrm{~N}$ & 18 & 18 \\
ILECTC2 & Pearson Correlation & $.901\left(^{* *}\right)$ & 1 \\
& Sig. (2-tailed) & .000 & \\
& $\mathrm{~N}$ & 18 & 18 \\
\hline
\end{tabular}

** Correlation is significant at the 0.01 level (2-tailed). 
Table 7. Correlations

\begin{tabular}{|cl|c|c|}
\hline & & LECTD1 & LECTD2 \\
\hline LECTD1 & Pearson Correlation & 1 & $-.589\left(^{*}\right)$ \\
& Sig. (2-tailed) & & .010 \\
& $\mathrm{~N}$ & 18 & 18 \\
LECTD2 & Pearson Correlation & $-.589\left(^{*}\right)$ & 1 \\
& Sig. (2-tailed) & .010 & \\
& $\mathrm{~N}$ & 18 & 18 \\
\hline
\end{tabular}

* Correlation is significant at the 0.05 level (2-tailed).

Table 8. Correlations

\begin{tabular}{|cl|c|c|}
\hline & & ILECTD1 & ILECTD2 \\
\hline ILECTD1 & Pearson Correlation & 1 & $.796\left(^{* *}\right)$ \\
& Sig. (2-tailed) & & .000 \\
& $\mathrm{~N}$ & 23 & 23 \\
ILECTD2 & Pearson Correlation & $\left..7966^{* *}\right)$ & 1 \\
& Sig. (2-tailed) & .000 & \\
& $\mathrm{~N}$ & 23 & 23 \\
\hline
\end{tabular}

** Correlation is significant at the 0.01 level (2-tailed).

Table 9. Correlations

\begin{tabular}{|ll|c|c|}
\hline & & CLECTA1 & CLECTA2 \\
\hline CLECTA1 & Pearson Correlation & 1 & $.548\left(^{*}\right)$ \\
& Sig. (2-tailed) & & .043 \\
& $\mathrm{~N}$ & 14 & 14 \\
CLECTA2 & Pearson Correlation & $.548\left(^{*}\right)$ & 1 \\
& Sig. (2-tailed) & .043 & \\
& $\mathrm{~N}$ & 14 & 14 \\
\hline
\end{tabular}

* Correlation is significant at the 0.05 level (2-tailed). 
Table 10. Correlations

\begin{tabular}{|cl|c|c|}
\hline & & ICLECTA1 & ICLECTA2 \\
\hline ICLECTA1 & Pearson Correlation & 1 & $.546\left(^{*}\right)$ \\
& Sig. (2-tailed) & & .035 \\
& $\mathrm{~N}$ & 15 & 15 \\
ICLECTA2 & Pearson Correlation & $.546\left(^{*}\right)$ & 1 \\
& Sig. (2-tailed) & .035 & \\
& $\mathrm{~N}$ & 15 & 15 \\
\hline
\end{tabular}

* Correlation is significant at the 0.05 level (2-tailed).

Table 11. Correlations

\begin{tabular}{|ll|c|c|}
\hline & & CLECTB1 & CLECTB2 \\
\hline CLECTB1 & Pearson Correlation & 1 & $.675(* *)$ \\
& Sig. (2-tailed) & & .008 \\
& $\mathrm{~N}$ & 14 & 14 \\
CLECTB2 & Pearson Correlation & $.675(* *)$ & 1 \\
& Sig. (2-tailed) & .008 & \\
& $\mathrm{~N}$ & 14 & 14 \\
\hline
\end{tabular}

** Correlation is significant at the 0.01 level (2-tailed).

Table 12. Correlations

\begin{tabular}{|ll|c|c|}
\hline & & ICLECTB1 & ICLECTB2 \\
\hline ICLECTB1 & Pearson Correlation & 1 & $.763(* *)$ \\
& Sig. (2-tailed) & & .001 \\
& $\mathrm{~N}$ & 15 & 15 \\
ICLECTB2 & Pearson Correlation & $.763\left(^{* *}\right)$ & 1 \\
& Sig. (2-tailed) & .001 & \\
& $\mathrm{~N}$ & 15 & 15 \\
\hline
\end{tabular}

** Correlation is significant at the 0.01 level (2-tailed). 
Table 13. Correlations

\begin{tabular}{|cl|c|c|}
\hline & & CLECTC1 & CLECTC2 \\
\hline CLECTC1 & Pearson Correlation & 1 & $.729\left(^{* *}\right)$ \\
& Sig. (2-tailed) & & .003 \\
& $\mathrm{~N}$ & 14 & 14 \\
CLECTC2 & Pearson Correlation & $.729(* *)$ & 1 \\
& Sig. (2-tailed) & .003 & \\
& $\mathrm{~N}$ & 14 & 14 \\
\hline
\end{tabular}

** Correlation is significant at the 0.01 level (2-tailed).

Table 14. Correlations

\begin{tabular}{|ll|c|c|}
\hline & & ICLECTC1 & ICLECTC2 \\
\hline ICLECTC1 & Pearson Correlation & 1 & $.787\left(^{* *}\right)$ \\
& Sig. (2-tailed) & & .001 \\
& $\mathrm{~N}$ & 15 & 15 \\
ICLECTC2 & Pearson Correlation & $.787\left(^{* *}\right)$ & 1 \\
& Sig. (2-tailed) & .001 & \\
& $\mathrm{~N}$ & 15 & 15 \\
\hline
\end{tabular}

** Correlation is significant at the 0.01 level (2-tailed).

Table 15. Correlations

\begin{tabular}{|ll|c|c|}
\hline & & CLECTD1 & CLECTD2 \\
\hline CLECTD1 & Pearson Correlation & 1 & $.944(* *)$ \\
& Sig. (2-tailed) & & .000 \\
& $\mathrm{~N}$ & 15 & 15 \\
CLECTD2 & Pearson Correlation & $.944(* *)$ & 1 \\
& Sig. (2-tailed) & .000 & \\
& $\mathrm{~N}$ & 15 & 15 \\
\hline
\end{tabular}

** Correlation is significant at the 0.01 level (2-tailed). 
Table 16. Correlations

\begin{tabular}{|ll|c|c|}
\hline & & ICLECTD1 & ICLECTD2 \\
\hline ICLECTD1 & Pearson Correlation & 1 & $.874\left(^{* *}\right)$ \\
& Sig. (2-tailed) & & .000 \\
& $\mathrm{~N}$ & 23 & 23 \\
ICLECTD2 & Pearson Correlation & $.874\left(^{* *}\right)$ & 1 \\
& Sig. (2-tailed) & .000 & \\
& $\mathrm{~N}$ & 23 & 23 \\
\hline
\end{tabular}

** Correlation is significant at the 0.01 level (2-tailed).

**Legend LECTA1 $=$ Lecturer A'S ratings

ILECTA1 $=$ Items on lecturer A ratings

CLECTA $=$ Course taught by lecturer A

ICLECTA $=$ Items on course taught by lecturer A

Table 17. Summary of correlation coefficients of the two instruments

\begin{tabular}{|c|c|c|c|c|}
\hline Lecturer & $\begin{array}{c}\text { Correlation Coefficient } \\
\text { of lecturer ratings }\end{array}$ & $\begin{array}{c}\text { Correlation Coefficient of } \\
\text { Items on lecturer ratings }\end{array}$ & $\begin{array}{c}\text { Correlation Coefficient } \\
\text { of Course ratings }\end{array}$ & $\begin{array}{c}\text { Correlation } \\
\text { Coefficient of Items } \\
\text { on course ratings }\end{array}$ \\
\hline Lect A1 & $-0.567 @ 0.05$ & $0.522 @ 0.05$ & $0.548 @ 0.05$ & $0.546 @ 0.05$ \\
\hline Lect B1 & $0.546 @ 0.05$ & $0.475 @ 0.05$ & $0.675 @ 0.01$ & $0.763 @ 0.01$ \\
\hline Lect C1 & $0.591 @ 0.05$ & $0.901 @ 0.01$ & $0.729 @ 0.01$ & $0.787 @ 0.01$ \\
\hline Lect D1 & $-0.589 @ 0.05$ & $0.796 @ 0.01$ & $0.944 @ 0.01$ & $0.874 @ 0.01$ \\
\hline
\end{tabular}

*All 16 coefficients were significant at either 0.05 0r 0.01 level of significance. 


\section{Appendix I}

\section{LECTURER EVALUATION FORM FOR STUDENTS}

Lecturer's Name:

Course Code:

Course Title:

Semester/Year:

\section{Instruction:}

Please rate the lecturer by ticking $(\sqrt{ })$ in the column that best expresses your extent of agreement with the statements where Strongly Agree $=5$, Agree $=4$, Not sure $=3$, Disagree $=2$, Strongly Disagree $=1$

\begin{tabular}{|c|c|c|c|c|c|c|}
\hline $\mathbf{S} / \mathbf{N}$ & STATEMENT & SA & $\mathbf{A}$ & NS & D & SD \\
\hline 1 & Lecturer communicated clearly & & & & & \\
\hline 2 & Lecturer provided clarifying examples & & & & & \\
\hline 3 & Lecturer was open to questions & & & & & \\
\hline 4 & Lecturer utilised different teaching methods & & & & & \\
\hline 5 & Lecturer managed class time effectively & & & & & \\
\hline 6 & Lecture was well organized & & & & & \\
\hline 7 & Lecturer did not do all the talking in class & & & & & \\
\hline 8 & Lecturer taught from the course content & & & & & \\
\hline 9 & Lecturer controlled the class effectively & & & & & \\
\hline 10 & Lecturer encouraged class discussion & & & & & \\
\hline 11 & Lecturer showed concern for students' learning progress & & & & & \\
\hline 12 & Lecturer treated students with respect & & & & & \\
\hline 13 & Lecturer gingered my interest in the course & & & & & \\
\hline 14 & Lecturer was regular to class & & & & & \\
\hline 15 & Lecturer was ready to help beyond class time & & & & & \\
\hline 16 & Lecturer gave students feedback on test/assignments & & & & & \\
\hline 17 & Lecturer was interested in students' understanding during class & & & & & \\
\hline 18 & Generally, the lecturer was very effective in teaching & & & & & \\
\hline
\end{tabular}




\section{Appendix II}

\section{COURSE EVALUATION FORM FOR STUDENTS}

Lecturer's Name:

Course Code:

Course Title:

Semester/Year:

\section{Instruction:}

Please rate the lecturer by ticking $(\sqrt{ })$ in the column that best expresses your extent of agreement with the statements where Strongly Agree $=5$, Agree $=4$, Not sure $=3$, Disagree $=2$, Strongly Disagree $=1$

\begin{tabular}{|c|c|c|c|c|c|c|}
\hline $\mathbf{S} / \mathbf{N}$ & STATEMENT & SA & $\mathbf{A}$ & NS & D & SD \\
\hline 1 & Organisation of course content was sequential & & & & & \\
\hline 2 & Course objectives was clearly indicated & & & & & \\
\hline 3 & Course content was covered & & & & & \\
\hline 4 & Completion of course content was thorough & & & & & \\
\hline 5 & Course content covered matched the stated course objectives & & & & & \\
\hline 6 & Course requirements were conveyed to students & & & & & \\
\hline 7 & Course was interesting to me & & & & & \\
\hline 8 & Course was not difficult to understand & & & & & \\
\hline 9 & Course increased my knowledge & & & & & \\
\hline 10 & Relevant course materials were available & & & & & \\
\hline 11 & Supportive teaching facilities for the course were available & & & & & \\
\hline 12 & Relevant assignments were given & & & & & \\
\hline 13 & Assignments given were challenging & & & & & \\
\hline 14 & Examination captured course objective & & & & & \\
\hline 15 & Overall, the course is worthwhile & & & & & \\
\hline
\end{tabular}

